\title{
THREE WIVES
}

Table and chair.

This is no marriage

but an arrangement.

Your first wife was the daughter of a man who built houses.

Each room left you emptier.

The second stood in the middle of rooms, auditoriums, fields and took her name, over and over, in vain.

The third had to be tracked down in snow, like a small animal suddenly run out of room.

Now she sits all day at her desk like Emily Dickinson, pure with poems.

\section{Stanley Plumly}

\section{FALL RAIN}

Thunder, old man and blind, grumbles from corners. Old too is rain that keeps falling, weakly falling, yet dissolves the roofs over all you remember into swamps again, it will take the sun centuries to dry them back into nothing. 